\title{
Contemporary Use of Traditional and Imported Food among Greenlandic Inuit
}

\author{
TINE PARS,${ }^{1}$ MERETE OSLER ${ }^{2}$ and PETER BJERREGAARD ${ }^{3}$
}

(Received 30 September 1999; accepted in revised form 25 July 2000)

\begin{abstract}
A health interview survey was carried out in Greenland in 1993-94 among randomly selected adult Inuit $(\mathrm{N}=1580)$ to gather information about people's perceptions of their own health and living conditions. Questions about preference for and frequency of consumption of selected traditional and imported food items were included in the questionnaire. Preference ratings show that traditional food was well liked in all age groups, but especially by the elders. The questionnaire showed more pronounced differences between age groups in how frequently traditional foods were consumed. Residence in a village or a remote part of the country, male gender, and a traditional upbringing were also good predictors of a high consumption of traditional food. On average, seal meat was the most frequently consumed traditional food, eaten daily by $20 \%$ of respondents, followed by fish (17\%), wildfowl $(10 \%)$, whale meat (6\%), and terrestrial animals (2\%). Imported food items like potatoes, cheese, and fruit syrup were consumed daily by more than $70 \%$. Two concerns for the future are the decreasing consumption of traditional food among the younger generations and the possible contribution of contaminants in traditional food to this trend.
\end{abstract}

Key words: traditional food, diet, food preferences, food frequency questionnaire, Greenland, Inuit

RÉSUMÉ. Une enquête par entrevue sur la santé a été menée au Groenland en 1993-1994 parmi des Inuits adultes (N = 1580) pris au hasard, afin de collecter de l'information sur la perception qu'avaient les gens de leur propre santé et de leurs conditions de vie. Le questionnaire portait entre autres sur la préférence pour certains aliments traditionnels et importés ainsi que sur la fréquence de leur consommation. Les taux de préférence montrent que les aliments traditionnels étaient très appréciés dans tous les groupes d'âges, mais surtout par les aînés. Le questionnaire révélait des différences plus nettes entre les groupes d'âges quant à la fréquence à laquelle les aliments traditionnels étaient consommés. Le fait d'habiter un village ou une région reculée du pays, l'appartenance au sexe masculin et une éducation traditionnelle étaient également de bons paramètres de prévision d'une grande consommation d'aliments traditionnels. En moyenne, la viande de phoque était l'aliment traditionnel consommé le plus fréquemment, soit sur une base quotidienne par 20 p. cent des répondants, suivie par le poisson (17 p. cent), le gibier à plume (10 p. cent), la viande de baleine (6 p. cent) et les animaux terrestres ( 2 p. cent). Des aliments importés comme la pomme de terre, le fromage et le sirop de fruit étaient consommés sur une base quotidienne par plus de 70 p. cent des répondants. La diminution chez les jeunes générations de la consommation d'aliments traditionnels et la contribution possible à cette tendance de la présence de contaminants dans les aliments traditionnels constituent deux sujets de préoccupation.

Mots clés: alimentation traditionnelle, régime, préférences alimentaires, questionnaire portant sur la fréquence de consommation de certains aliments, Groenland, Inuit

Traduit pour la revue Arctic par Nésida Loyer.

\section{INTRODUCTION}

Scientific interest in the use of traditional food by the Greenlandic Inuit (Kalaallit) began early in the 20th century with a study of protein degradation in the human body (Krogh and Krogh, 1913). By the middle of the century, the colonial authorities were concerned about the nutritional status of Kalaallit because of westernization of the diet (Uhl, 1955). In the 1970s, the lipid metabolism in Kalaallit was studied to test a hypothesis linking low mortality from ischaemic heart disease to the consumption of marine animals (Dyerberg et al., 1975). During the last decade, there has been increasing concern about the possible health-damaging effects of traditional food pollution by several environmental contaminants in the circumpolar North. This concern has resulted in an international monitoring program aimed at the environment as well as the Arctic peoples (AMAP, 1998).

Greenland has nearly 56000 inhabitants, of whom 49000 were born in Greenland and 7000 outside Greenland, mostly in Denmark. In official statistics, the place of birth is used as a proxy for ethnicity: according to this criterion, $88 \%$ of the population are Inuit. The country is divided into 17 municipalities. Of the total population, $80 \%$ live in towns with 500-13000 inhabitants, while the remainder live in approximately 60 villages with $40-500$ inhabitants.

\footnotetext{
${ }^{1}$ P.O. Box 1626, DK-3900 Nuuk, Greenland; tine@ @uka.gl

${ }^{2}$ Institut for Folkesundhed, Københavns Universitet, Blegdamsvej 3, DK- 2200 Copenhagen N, Denmark

${ }^{3}$ Statens Institut for Folkesundhed, Svanemøllevej 25, DK-2100 Copenhagen Ø, Denmark

(C) The Arctic Institute of North America
} 
The number of people (in percent of total population) living in villages has decreased from 25\% in 1969 to $17 \%$ in 1999. Subsistence fishing and hunting, commercial fishing, and employment in the related processing industry are the most important occupations, while subsidies from Denmark account for about half of this mixed economy. In $71 \%$ of the families who earn their living from hunting and fishing (including crewmembers on fishing trawlers), at least one partner (in most cases the wife) has supplementary income as a wage earner (Grønlands Statistik, 1995a). In the towns, $10 \%$ of the adult population (men and women) are fishermen or hunters or both. In the villages, this number is $28 \%$, and in the northernmost villages, up to $40 \%$ of the adults are fishermen/hunters (Grønlands Statistik, 1995b). In the northern and eastern parts of the country, the supply of imported food such as fresh fruit and vegetables is limited, because the sea ice impedes boat traffic during several months each winter.

Our objectives are to describe the frequency of consumption of selected traditional and imported food items in a countrywide sample representative of the total Greenlandic population, to analyze preference ratings for traditional and imported food items, and to identify some of the reasons why traditional food is not eaten more often.

\section{Historical Aspects of Traditional Food}

In the West Greenlandic Inuit language, traditional food is called kalaalimineq (plural kalaalimernit, from kalaaleq 'a Greenlander' + -mineq 'piece of' or 'kind of'). Imported food is called Qallunaamineq (from Qallunaaq 'a Dane'). Traditional food includes various species of fish, wildfowl, seal, whale, caribou, muskox, and hare, as well as certain plant foods.

Before World War II, Greenland was a very isolated community with a widely scattered population. Until the 19th century, several families had usually lived together in one house and the food, almost exclusively of animal origin, was distributed among and within the families according to specific rules (Petersen, 1989). When Danish colonization began in 1721, the Danish authorities prohibited the selling of imported European food to Kalaallit. But despite the strict regulations about to whom, how, and when the European foods could be allowed, the Kalaallit knew the taste of coffee, grain, tobacco, and other goods, which they obtained through barter with European whalers and illegal trade with Danish employees. Not until 1860 did it become legal to sell coffee, tea, bread, and grain freely to Kalaallit in general. Later in the 19th century, more people became wage earners, and the hunters began selling traditional food not only to the Danes but also to Kalaallit (Marquardt and Caulfield, 1996).

Today these transactions take place at the kalaalimineerniarfik ("place where Greenlandic food is sold'), a local market where fresh catches can be bought directly from the hunters or from a person selling on their behalf. Traditional food can also be bought in the shops and supermarkets, where different kinds of goods (mostly frozen) are available. The primary provider of these goods is the Home Rule-controlled company Nuka A/S, which is responsible for producing, processing, marketing, and distributing the products of Greenlandic fisheries. Not only full-time hunters go fishing or hunting for seals and wildfowl. Many wage earners have their own boats and supply their households with their own catch. Urbanization has changed the habitation patterns and family structures, and the distribution of meat in hunting families to family members now has a social function rather than being a necessary subsistence arrangement (Hertz, 1995). The imported food items in shops and supermarkets are by and large similar to those sold in Denmark, but prices are considerably higher.

Among the five species of seal in Greenland, the most common are ringed seal and harp seal (Table 1). The cetaceans most commonly hunted are the baleen whales (the fin whale and the minke whale) and the small cetaceans (narwhal, beluga, and harbour porpoise). The seals and baleen whales are widespread along the coast. Catch quotas for the hunt of the baleen whales conform to the "aboriginal subsistence whaling" management regime of the International Whaling Commission (IWC). Harbour porpoise is hunted in the southwestern part of the country, narwhal in the northern and eastern part, and beluga in the northern part (Heide-Jørgensen, 1994). The whales are mostly caught during their migrations to summer and wintering grounds along the coast, and there is accordingly a pronounced seasonal variation in the consumption of the whales. The most common fish are Greenland halibut, Atlantic cod, Greenland cod, arctic char, salmon, lumpfish, redfish, catfish, and capelin. The most commonly consumed wildfowl are Brünnich's guillemot, common eider, black-legged kittiwake, black guillemot, and little auk (in the North). Caribou is the most commonly used of the terrestrial species. It is most abundant on the southwest coast and is rarely seen in East Greenland. Muskox is present in only a few areas.

During the last 50 years, the change towards a modern industrial society, which started around the turn of the last century, has gained considerable momentum. However, the modernization process in the larger towns on the central west coast is very different from that in the villages, where life in general is more traditional and subsistence hunting and fishing are still economically important. This modernization has had a considerable influence on dietary habits and the use of traditional and imported food. Only a few studies have been carried out on food consumption and dietary habits in Greenland during the last 25 years. In 1974, the Danish National Council for Domestic Science conducted interviews among households in West Greenland (Brenøe, 1975). During the 1970s, Bang and Dyerberg (1981) carried out nutrition surveys among hunters in Northwest Greenland, and Helms (1981) used food supply lists to estimate the use of imported and locally produced food in East Greenland in the period 1949-79. 
TABLE 1. Common and scientific names for traditional foods mentioned in the text.

\begin{tabular}{ll}
\hline \hline Ringed seal & Phoca hispida \\
Harp seal & Pagophilus groenlandicus \\
Fin whale & Balaenoptera physalus \\
Minke whale & Balaenoptera acutorostrata \\
Narwhal & Monodon monoceros \\
Beluga & Delphinapterus leucas \\
Harbour porpoise & Phocoena phocoena \\
Greenland halibut & Reinhardtius hippoglossoides \\
Atlantic cod & Gadus morhua \\
Greenland cod & Gadus ogac \\
Arctic char & Salvelinus alpinus \\
Atlantic Salmon & Salmo salar \\
Lumpfish & Cyclopterus lumpus \\
Redfish & Sebastes marinus \\
Catfish & Anarhichas lupus/minor \\
Capelin & Mallotus villosus \\
Brünnich's guillemot & Uria lomvia \\
Common eider & Somateria mollissima \\
Black guillemot & Cepphus grylle \\
Little auk & Alle alle \\
Caribou & Rangifer tarandus groenlandicus \\
Muskox & Ovibos moschatus \\
\hline \hline
\end{tabular}

More recently, three dietary surveys were carried out, one among children in the capital, Nuuk (Helms, 1985), one among households in North Greenland (Helms and Torell, 1987), and one among adults in two villages in the Disko Bay area (Pars, 1992). These studies show that the use of traditional food has decreased through the years. For example, in the villages in Northwest Greenland, traditional food supplied 54\% of the daily energy intake in 1952 (Uhl, 1955), but this figure had dropped to $25 \%$ in 1991 (Pars, 1992). The studies also show that traditional food is more frequently used in villages than in towns, and that the young generation does not use traditional foods as often as the elder generation. However, there are no countrywide studies of the dietary habits of the Kalaallit.

\section{METHODS}

The present data are derived from a population-based health interview survey in Greenland, which was carried out in 1993-94 (Bjerregaard and Young, 1998; Bjerregaard et al., 1999). The purpose of the study was to obtain information about people's own opinions on their health status, living conditions, daily life, and the health care system. The study was given ethical approval by the Commission for Scientific Research in Greenland and all participants gave their informed consent prior to the interview.

A total of 3025 individuals aged 18+ were selected randomly from the national population register. Of these, 2425 were visited by interviewers, and an interview was obtained from $1728(71 \%)$. Only those who identified themselves as Kalaallit were included in the present analysis. The interviews were conducted from June 1993 to July 1994 by 69 interviewers. Information was obtained on sociodemographic and cultural background variables, living conditions, lifestyle, and health. The interview included questions about dietary preferences and about the consumption of selected food items. Information on food preferences was derived from a list of 12 traditional and 12 imported food items. Respondents were asked to rate how much they liked each food item on a scale from 1 (= dislike) to 5 (= like very much). Information on consumption was derived from an interview-based food frequency questionnaire in which participants were asked how many times during the last three months they had eaten meat from 5 different traditional food items and 12 imported food items. The answer categories were "every day," "4-6 times per week," " $1-3$ times per week," " $2-3$ times per month," "once a month or less," and "never."

Dietary habits were studied in relation to age, gender, place of residence, occupation, and childhood conditions. Indices of tradition and acculturation were calculated from information on residence during childhood, proficiency in Greenlandic and Danish language, parents' place of birth, and parents' occupation. By cross-tabulating these two indices, we divided the population into four major subgroups: 1) Persons with a Danish upbringing. These were mostly salaried employees currently living in towns. 2) Persons who had grown up in Greenlandic towns. These currently lived in towns and had all types of occupations, but were mostly salaried employees. 3) Persons who had grown up in villages or in towns in remote areas, such as the east coast or the northernmost part of the west coast. These currently lived in towns or villages, and many of them were hunters or unskilled workers. 4) Persons who had grown up in villages. These currently lived in towns or villages and many of them were hunters or unskilled workers.

Univariate analysis of variance, $t$-test for equality of means of independent and paired samples, multiple regression, logistic regression, and the chi-square test were used to test the significance of differences between the subgroups. For some of the statistical analyses, the frequency categories were transformed into times per month $(\mathrm{tpm})$, as follows: every day $=30.4 \mathrm{tpm} ; 4-6$ times per week $=21.7 \mathrm{tpm} ; 1-3$ times per week $=8.7 \mathrm{tpm} ; 2-3$ times per month $=2.5 \mathrm{tpm}$; and once a month or less $=1 \mathrm{tpm}$. For statistical analyses, SPSS version 8.0 was used. All analyses were repeated using nonparametric statistics, which gave similar results.

\section{RESULTS}

The present analyses comprise data from 1580 participants who consider themselves Kalaallit. The participants lived in all 17 towns and in 21 randomly selected villages from the whole country. Figure 1 shows all the places where interviews were conducted.

\section{Food Preferences}

Traditional food items were rated significantly higher (mean score 4.67, SD 0.43) than imported foods (4.10, 


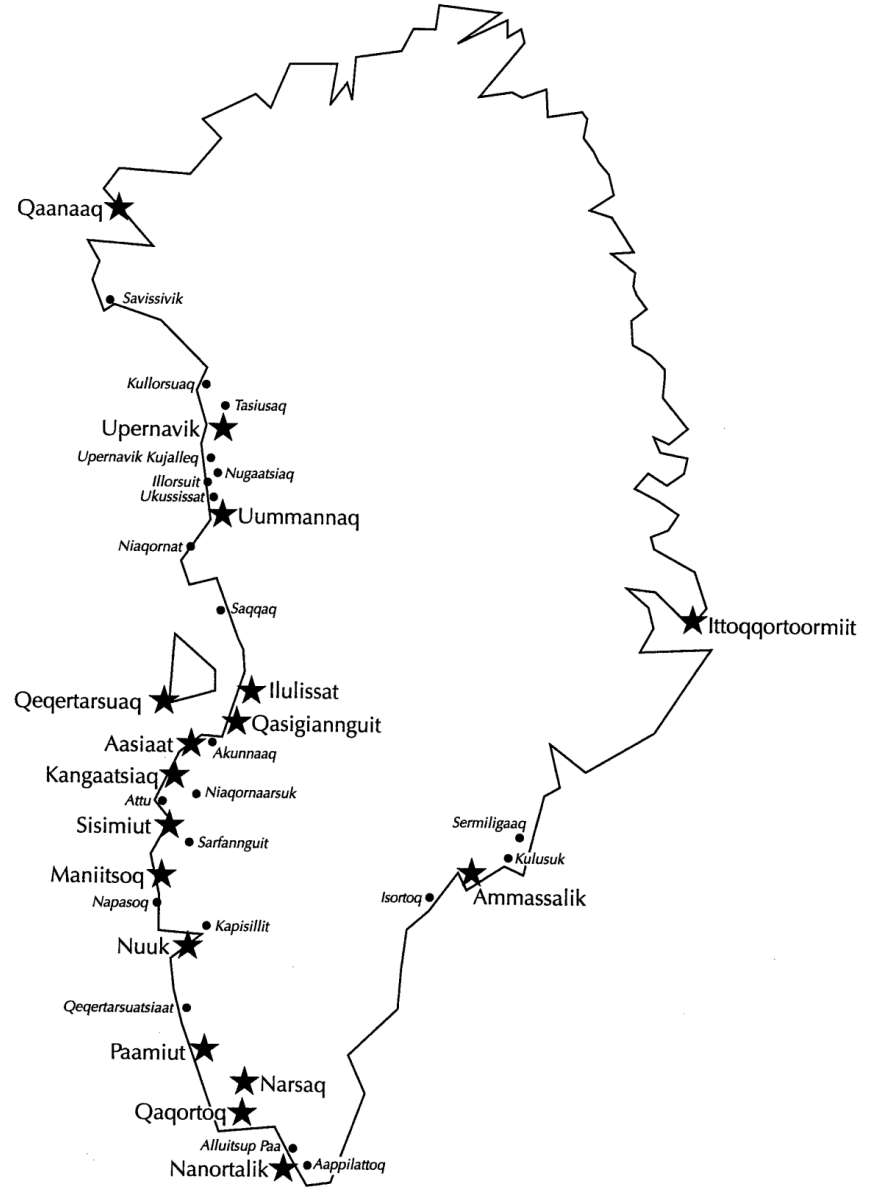

FIG. 1. Map of Greenland showing the towns and villages included in the survey. Stars indicate towns, and dots indicate villages. In this article, the North West region is considered to start from Sarfannguit and extend up to Qaanaaq.

SD 0.59). Mattak (whale skin), Brünnich's guillemot, dried cod, crowberries, and seal meat were the most popular traditional items, while rye bread, potatoes, vegetables, apples, and mutton were the most preferred imported foods. All age groups gave high rates to traditional food, but preference rates increased with age. Table 2 shows the preference rates for the youngest and the eldest age groups (18-24 and 60+ year olds). There were significant differences between the two age groups for several of the traditional food items. The age differences were not as pronounced for the imported food, but young people rated vegetables, apples, and Danish pastry higher than did those aged 60 or more.

Men and women had the same preferences for most of the food items, but women gave higher ratings than men to crowberries, dried cod, and guillemot from the traditional food group, and to vegetables, potatoes, apples, and rye bread from the imported food group. On the other hand, men rated pork sausage and Danish pastry higher than women did. When the sum of ratings for all traditional foods was divided into thirds, $57 \%$ of respondents living with a non-Inuit partner compared to $31 \%$ of respondents living with another Kalaaleq, gave rates in the lower third (chi-square test, $p=0.000$ ).

There were significant differences between towns and villages with regard to preferences for the traditional and imported food groups as well as for several of the individual food items (Table 2). Persons who live in towns at present but grew up in villages rated traditional food significantly higher (mean score 4.77, SD 0.31) than did those who grew up in towns (4.63, SD 0.42) or in a Danish environment (4.04, SD 0.77). For imported food there were no significant differences between the groups with different childhoods.

\section{Consumption of Traditional and Imported Food}

Figure 2 shows the percentages of respondents who daily (four times or more per week) consumed the different food items listed in the questionnaire. Among the five traditional foods listed, seal meat was eaten daily by $21 \%$ of the respondents, fish by $17 \%$, and wildfowl by $10 \%$. Whale meat was eaten daily by $6 \%$ of the respondents, and terrestrial animals (caribou, muskox, and hare) by $2 \%$. Among the 12 listed imported foods, potatoes, cheese, and fruit syrup were used daily by more than $75 \%$ of the respondents. Eggs, milk, butter, fruit, and vegetables were consumed daily by more than $40 \%$, while very few subjects (less than 5\%) consumed mutton and canned or frozen dishes daily.

The sum of the frequencies of all of the traditional food items (seal, whale, fish, birds, and terrestrial animals) gives a relative estimate of the total consumption of traditional food. Using this estimate, we found that traditional food was consumed on average 29.3 times per month.

Figure 3 shows the differences between men and women and between different age groups in the consumption of traditional foods. The older subjects consumed traditional food items more often than the younger age groups. However, for terrestrial animals the age differences were small. The difference between the generations was most clear in the towns where the older subjects consumed traditional food almost twice as often as the youngest age group (data not shown). Table 3 gives the use of imported food groups related to gender and age. The youngest age groups consumed fruit and vegetables, fruit syrup, and soft drinks more often than the oldest $(p<0.01)$, while for dairy products there was no difference.

Men consumed seal and whale meat more often than did women, while there was no difference for the other traditional food items. The differences between men and women in the frequency of consumption of seal and whale meat were higher in the villages than in the towns except in the oldest age group. Among imported foods, fruit and vegetables and dairy products were used more often by women than by men (Table 3), while for soft drinks and fruit syrup there was no difference between genders. Living together with a person of another ethnicity (primarily Danish) influenced the consumption of traditional food. Women 
TABLE 2. Mean food preference ratings of 1580 Greenland Inuit in 1993-94, showing comparisons of two age groups (18-24 v. 60+ years) and towns v. villages. Rating scale is from 1 (= dislike) to 5 (= like very much). Ratings are given as mean (SD).

\begin{tabular}{|c|c|c|c|c|}
\hline Food item & $\begin{array}{l}\text { Age } 18-24 \\
\text { Mean (SD) } \\
\mathrm{N}=224\end{array}$ & $\begin{array}{l}\text { Age } 60+ \\
\text { Mean }(\mathrm{SD}) \\
\mathrm{N}=207\end{array}$ & $\begin{array}{l}\text { Towns } \\
\text { Mean (SD) } \\
\mathrm{N}=1212\end{array}$ & $\begin{array}{l}\text { Villages } \\
\text { Mean (SD) } \\
\mathrm{N}=334\end{array}$ \\
\hline \multicolumn{5}{|l|}{ Traditional Foods } \\
\hline Mattak $^{1}$ & $4.83(0.71)$ & $4.88(0.53)$ & $4.88(0.57)$ & $4.88(0.56)$ \\
\hline Dried cod & $4.70(0.87)$ & $4.76(0.85)$ & $4.81(0.69)^{* *}$ & $4.95(0.39)$ \\
\hline Brunnich's guillemot & $4.49(1.06)^{* *}$ & $4.97(0.20)$ & $4.80(0.68)$ & $4.80(0.73)$ \\
\hline Crowberries & $4.66(0.86)$ & $4.75(0.75)$ & $4.77(0.69)$ & $4.82(0.70)$ \\
\hline Seal meat & $4.46(1.01)^{* *}$ & $4.74(0.86)$ & $4.67(0.85)^{* *}$ & $4.87(0.54)$ \\
\hline Qullukkat $^{2}$ & $4.47(1.09)^{*}$ & $4.68(0.91)$ & $4.65(0.90)^{* *}$ & $4.80(0.73)$ \\
\hline Whale meat & $4.27(1.23) * *$ & $4.67(0.93)$ & $4.64(0.88)$ & $4.73(0.84)$ \\
\hline Caribou meat & $4.36(1.24)$ & $4.37(1.27)$ & $4.57(1.03)^{* *}$ & $4.31(1.34)$ \\
\hline Dried whale meat & $4.12(1.43)^{* *}$ & $4.57(1.02)$ & $4.54(1.04)$ & $4.64(1.02)$ \\
\hline Greenland halibut & $4.18(1.17)^{* *}$ & $4.62(0.91)$ & $4.47(1.02)^{* * *}$ & $4.69(0.80)$ \\
\hline Wolf fish & $3.98(1.29)^{* *}$ & $4.70(0.93)$ & $4.44(1.06) * *$ & $4.64(0.97)$ \\
\hline Seal liver & $3.54(1.66)^{* *}$ & $4.55(1.12)$ & $4.11(1.43)^{* *}$ & $4.53(1.08)$ \\
\hline All traditional foods & $4.36(0.65) * *$ & $4.71(0.40)$ & $4.66(0.44) * *$ & $4.74(0.41)$ \\
\hline \multicolumn{5}{|l|}{ Market Foods } \\
\hline Rye bread & $4.72(0.68)$ & $4.69(0.73)$ & $4.74(0.63)^{*}$ & $4.82(0.58)$ \\
\hline Potatoes & $4.65(0.79)$ & $4.67(0.76)$ & $4.73(0.63)^{* *}$ & $4.84(0.57)$ \\
\hline Vegetables & $4.71(0.72)^{* *}$ & $4.27(1.15)$ & $4.65(0.77)$ & $4.59(0.94)$ \\
\hline Apples & $4.83(0.57)^{* *}$ & $3.83(1.39)$ & $4.60(0.87)$ & $4.53(1.10)$ \\
\hline Lamb & $4.21(1.27)$ & $4.36(1.20)$ & $4.57(0.97)^{* *}$ & $4.03(1.41)$ \\
\hline Cheese & $4.39(1.14)$ & $4.51(1.01)$ & $4.48(0.99)$ & $4.49(1.13)$ \\
\hline Liver paste & $4.30(1.07)$ & $4.19(1.18)$ & $4.18(1.12)^{*}$ & $4.36(1.17)$ \\
\hline Hamburger & $3.90(1.19)$ & $3.76(1.44)$ & $3.80(1.26)$ & $3.77(1.43)$ \\
\hline Pork chops & $3.85(1.27)$ & $3.58(1.49)$ & $3.64(1.33)$ & $3.78(1.42)$ \\
\hline Danish pastry & $3.94(1.25)^{* *}$ & $3.32(1.55)$ & $3.55(1.42)^{* *}$ & $3.96(1.46)$ \\
\hline Chicken & $3.34(1.50)$ & $3.26(1.51)$ & $3.13(1.43) * *$ & $3.46(1.61)$ \\
\hline Medisterpølse (sausage) & $3.07(1.43)$ & $3.23(1.56)$ & $2.84(1.44)^{* *}$ & $3.53(1.53)$ \\
\hline All store-bought food & $4.17(0.58) * *$ & $3.96(0.69)$ & $4.08(0.58) * *$ & $4.19(0.61)$ \\
\hline
\end{tabular}

${ }^{*}=p<0.05, * *=p<0.01$.

${ }^{1}$ Whale skin.

${ }^{2}$ Freeze-dried Greenland halibut.

living with Greenlandic partners consumed traditional food $28.4 \mathrm{tpm}$, while women with Danish partners consumed traditional food only $18.3 \mathrm{tpm}(p<0.01)$, irrespective of age and place of residence. This difference was also significant $(p<0.05)$ for men: traditional food was consumed $32.7 \mathrm{tpm}$ by men with a Greenlandic partner and 17.9 tpm by those with a Danish partner.

The place of residence (town or village and region) was associated with the frequency of consumption of traditional food. Subjects living in villages or in the northern part of the country consumed more traditional food than did those in the towns or the southern part of the country (Fig. 4). The regional difference was most pronounced for seal, and the consumption of birds and whale meat was twice as high in the northwestern villages as in other regions. All imported food items taken together were used more often in towns than in villages, while there were no significant differences between towns and villages for canned and frozen dishes, eggs, milk, and fruit syrup (Table 4). In East Greenland, whale meat and terrestrial animals were consumed less frequently than elsewhere. In the eastern villages, seal meat was consumed more often (21 tpm) than in all other places $(5-18 \mathrm{tpm})$, while imported food (except soft drinks and canned or frozen dishes) was consumed much less often.
A traditional childhood was associated with the frequent use of traditional food in adulthood regardless of the current place of residence (linear regression, controlled for age and place of residence in town or village). Participants who lived in towns but grew up in villages consumed traditional food 31 times per month, while participants with a Danish childhood consumed traditional food only 17 times per month $(p<0.01)$. Respondents who grew up in villages consumed fruit and vegetables 50 times per month, while for respondents with a Danish childhood the frequency was 60 times per month $(p<0.01)$. The same two groups consumed dairy products 50 and 65 times per month, respectively $(p<0.01)$.

\section{Reasons for Not Eating Traditional Foods More Often}

Except for those who reported that they consumed traditional food every day, the participants were asked to give their reasons for not eating traditional food more often. Respondents' three most frequent answers were that they wished to vary their diet (48\%); that it was difficult to obtain traditional food $(45 \%)$; and that traditional food was expensive (39\%).

The wish for variation in the diet decreased with age, and more participants in the villages than in the towns 


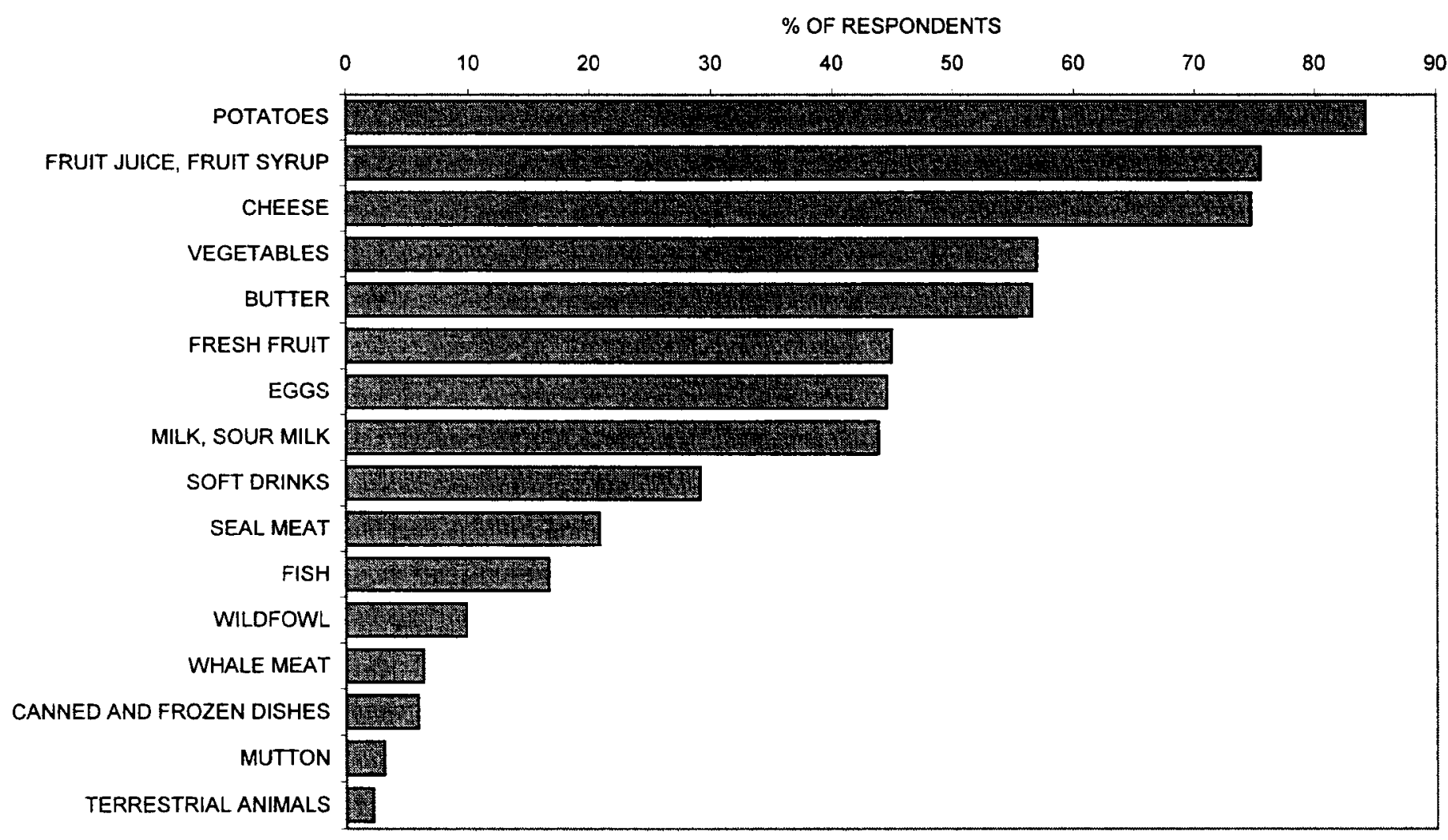

FIG. 2. Percent of 1580 Inuit respondents in Greenland that consumed different food items daily (more than 4 times a week) in $1993-94$.

stated this reason (Table 5). In both southwestern and northwestern villages, $70 \%$ indicated this reason compared with $45-57 \%$ in the towns on the west coast and only $6-15 \%$ in eastern towns and villages and in North Greenland.

Slightly more young respondents (49\%) compared with the elders (43\%) and slightly more women (47\%) than men $(42 \%)$ indicated difficulty in obtaining traditional food as a reason for not eating traditional food more often, but the differences were not significant. More people in the villages (59\%) compared with the towns (43\%) indicated that it was difficult to obtain traditional food. In Nuuk, only $28 \%$ indicated that it was difficult to obtain traditional food, while this reason was given by $88 \%$ in eastern towns, $74 \%$ in eastern villages, and $79 \%$ in North Greenland. Finding the prices of traditional food too high was associated with increasing age, and more respondents in the towns $(42 \%)$ than in the villages $(22 \%)$ had this as a reason for not eating traditional food more often. Only very few (1\%) stated that fear of contaminants had influenced how often they consumed traditional food.

\section{DISCUSSION}

The present population-based study has shown that traditional food is highly appreciated by the Kalaallit. The young people's preference ratings for traditional food are not much different from those of the older people, but their frequency of consumption is much lower. Traditional food

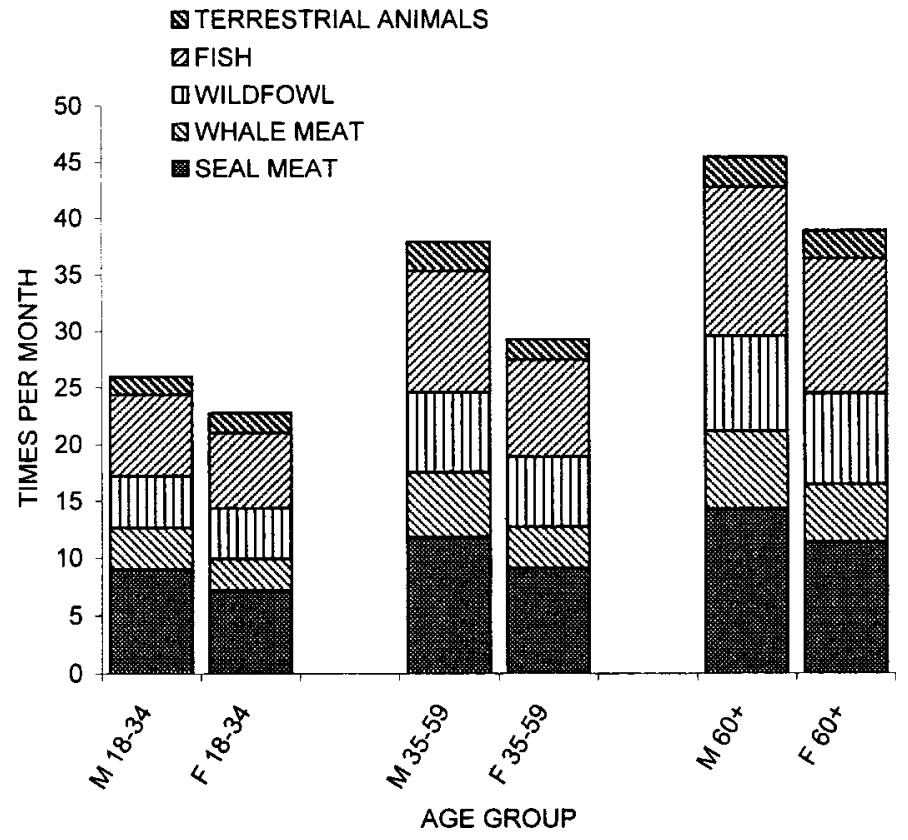

FIG. 3. Mean frequency of consumption of traditional food (in times per month) by 1580 Inuit in Greenland in 1993-94, showing men $(\mathrm{M})$ and women $(\mathrm{F})$ in different age categories. One-way ANOVA test for trend $(p<0.01)$.

items available only in a limited period were rated highest, while the highest rates given to imported foods were assigned to staples such as rye bread and potatoes. A traditional lifestyle during childhood has an effect on the consumption of traditional food as an adult. The consumption is also highly dependent on the current place of residence 
TABLE 3. Frequency of consumption (in times per month) of selected food groups by 1580 Greenland Inuit in 1993-94, shown in relation to age and gender. Frequencies are given as mean (SD).

\begin{tabular}{|c|c|c|c|c|c|c|}
\hline & \multicolumn{2}{|c|}{ Fruit and Vegetables } & \multicolumn{2}{|c|}{ Dairy Products } & \multicolumn{2}{|c|}{ Soft Drinks and Fruit Juice } \\
\hline & Men & Women & Men & Women & Men & Women \\
\hline \multicolumn{7}{|l|}{ Age } \\
\hline $18-34$ & $52.8(20.9)^{* *}$ & 60.5 (20.6) & $51.1(22.5)$ & $53.9(23.9)$ & $37.7(16.1)$ & $35.8(15.6)$ \\
\hline $35-59$ & $49.9(22.9)^{* *}$ & $58.5(22.4)$ & $50.2(24.8)^{* *}$ & $57.1(24.1)$ & $31.1(16.2)^{*}$ & $28.4(14.6)$ \\
\hline $60+$ & $39.1(22.1)^{*}$ & $45.8(22.0)$ & $47.8(29.1)$ & $55.0(26.0)$ & $25.9(17.1)$ & $24.3(15.5)$ \\
\hline All & $49.7(22.3)+$ & $57.9(21.9)+$ & $50.3(24.5)$ & $55.2(24.3)$ & $33.3(16.8)+$ & $31.6(15.9)+$ \\
\hline
\end{tabular}

${ }^{*}$ Significant difference between men and women: $=p<0.05$, ANOVA.

** Significant difference between men and women: $=p<0.01$, ANOVA.

${ }^{+}=$Significant difference between age groups in the use of fruit and vegetables and soft drinks and fruit syrup ( $p<0.01$, ANOVA).

in an urban or rural area, and northerners consume more traditional food than southerners do. Men consume traditional foods more often than women do, and having a nonInuit partner results in a lower rating and frequency of consumption of traditional food.

Those interviewed in the present study were representative of the general population in Greenland (Bjerregaard et al., 1999), and our data on the frequency of consumption of traditional food are in agreement with results from another recent study by Statistics Greenland (Grønlands Statistik, 1996).

Questions about food preferences can provide information on the cultural and social importance of food (Wein et al., 1996). However, preference for traditional food is not a sufficient predictor of its consumption, as the availability of traditional food items depends on several factors, such as the time of the year, availability in the stores, and contact with hunters. Although preference ratings for traditional food differed only slightly between the age groups, the difference in the frequency of consumption of traditional food was greater, with the elders consuming traditional food considerably more often than the young people. This fact indicates a better accord between the preference ratings and the frequency of consumption of traditional food among elders than among young people. A better concordance between attitudes and food habits among older people has also been found in other studies (Fürst, 1985).

The dependence on region and urbanization in the consumption of traditional food confirms what other studies have shown (Brenøe, 1975; Grønlands Statistik, 1995b). Seal meat and fish are the most commonly consumed traditional food items. While in the towns the consumption of seal and fish is almost similar, in the villages more seal meat than fish is consumed. The high consumption of seal among the village population living a more traditional, hunting-based life confirms the historical importance of the seal for traditional Greenlandic culture. From a different analytical perspective, Hovelsrud-Broda (1997:30) has concluded that for East Greenland hunters "the seal is the main link between the past and the present."

Studies have shown that eating traditional food, and especially seal meat, makes people feel satisfied and warm

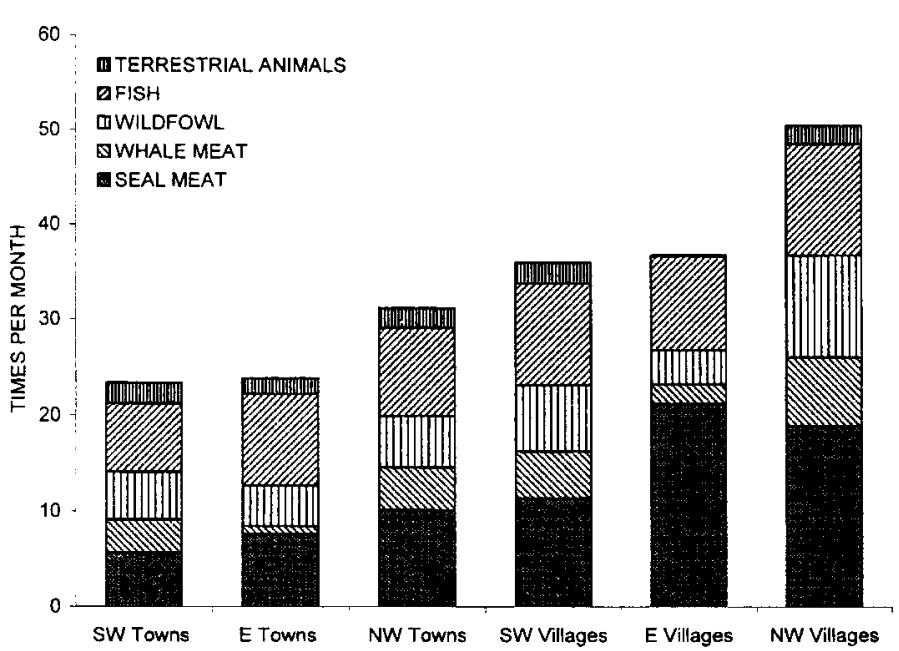

FIG. 4. Mean frequency of consumption (times per month) of traditional food by 1580 Inuit respondents in towns and villages of different Greenland regions, 1993-94. SW = South West, E = East, NW = North West.

(Borre, 1991; Curtis and Pars 1999, unpublished observations) and that men have higher levels of physical activity and more outdoor work than women (Bjerregaard et al., 1995). These results support the general opinion that men more than women experience a need to eat traditional food. A more frequent consumption of traditional food by men has also been described among native Canadians (Wein et al., 1991).

In 1974, $89 \%$ of Kalaallit consumed traditional food several times a week (Brenøe, 1975). Because of differences in the questions about consumption of traditional foods, it is not possible to make a similar estimate from the data in this study. However, comparing Brenøe's results with those from the present study, it seems appropriate to conclude that the frequency was higher in 1974. Age and place of residence were good predictors of traditional food consumption in the 1974 study as well as in ours. Other studies conducted among Inuit in Canada have also found that consumption of traditional food depends on age, gender, and urbanization (e.g., Jetté, 1995).

The consumption of imported food was higher in towns than in villages, but there was no regional variation. The consumption of fruit was highest among young people and 
TABLE 4. Frequency of consumption (times per month) of store-bought food by Inuit in towns and villages of Greenland in 1993-94. Frequencies are given as mean (SD).

\begin{tabular}{lrlrr}
\hline \hline Store bought food item & \multicolumn{2}{c}{ Towns } & \multicolumn{2}{c}{ Villages } \\
\hline Mutton & 3.8 & $(5.0)^{*}$ & 2.0 & $(3.1)$ \\
Prepared dishes & 2.8 & $(6.1)$ & 3.1 & $(6.6)$ \\
Potatoes & 23.5 & $(8.0)^{*}$ & 22.0 & $(8.9)$ \\
Other vegetables & 18.0 & $(10.5)^{*}$ & 11.3 & $(10.5)$ \\
Butter & 18.4 & $(13.4)^{*}$ & 12.3 & $(13.4)$ \\
Cheese & 22.9 & $(10.2)^{*}$ & 18.2 & $(11.7)$ \\
Eggs & 14.9 & $(10.7)$ & 14.5 & $(11.1)$ \\
Fresh fruit & 14.9 & $(11.3)^{*}$ & 11.6 & $(11.1)$ \\
Milk, sour milk & 14.0 & $(12.0)$ & 13.3 & $(11.5)$ \\
Soft drinks & 9.1 & $(10.6)^{*}$ & 12.4 & $(12.4)$ \\
Fruit syrup & 22.7 & $(11.1)$ & 22.1 & $(11.1)$ \\
Beer, wine or spirits & 4.1 & $(5.7)^{*}$ & 3.0 & $(4.8)$ \\
\hline \hline
\end{tabular}

${ }^{*} p<0.01$, one-way ANOVA.

among women. Looking at the changes through time, potato consumption has not changed over the last 20 years (5.3 times per week in Brenøe's study compared with 5.4 times per week in the present study), but vegetables, butter, milk, and fruit are used more often now than in 1974.

The cost of traditional food is not an important reason why young people do not consume it more often; a wish for variation in the diet is more important. This fact can be associated with life in the modern society, where making food choices is equivalent to choosing what kind of life and what identity you wish to have (Holm, 1996). By eating modern imported food, young people signal their interest in being a part of the modern world; by their high appreciation of traditional food, they show that they value the Greenlandic culture; and by eating traditional food, they manifest their connection to that culture.

Eating kalaalimernit has been said to have a symbolic value as important for the culture as speaking Greenlandic (Petersen, 1985). Today traditional food culture in the towns is something you can buy and choose, whereas in the villages, traditional food culture cannot be bought and chosen: instead, you inherit the culture. In that perspective, the symbolic value of consuming traditional food must be different in the towns and villages. In towns, it will be more a symbol for appreciation of the Greenland culture, and in some cases even a status symbol. In villages, it will still be more an indication of one's position in the local community (as a good hunter) and, by the traditional sharing rules, will also indicate the strength of family bonds. This may explain why so many people in the villages indicate that traditional food is difficult to obtain. In the villages and remote places, traditional food is everyday food, and people are much more dependent on their own hunting (and procuring) efforts, while in towns, various kinds of traditional foods can be bought in the shops and the need to go hunting for food is not as pronounced. The importance of traditional foods for identity and for social and cultural values in the modern and traditional Greenlandic society has been described previously by Roepstorff (1997) and Sejersen (1998).

Consumption of traditional food must be seen in connection with the very high blood and tissue levels of mercury, PCBs, and pesticides in Inuit populations (AMAP, 1998). These contaminants originate from industry and agriculture at lower latitudes and are transported to the Arctic by winds and ocean currents. Exposure is particularly high in Greenland and the eastern Canadian Arctic. The contaminants are biomagnified in the marine food web and are present in high concentrations in the meat, blubber, and organs of marine mammals. However, the participants in the present study were not consciously affected in their choice of food by the fear of contaminants. Recently there has been more attention to the contaminant issue in the press; a possible result is that more people will become afraid to eat traditional food. This is unfortunate because of the benefits for health from eating marine food. In Greenland, public health officials continue to recommend consumption of traditional food because nutritional values of these foods are believed to outweigh any risk from contaminants. Marine food is believed to reduce the incidences of ischaemic heart disease (Bang et al., 1980) and diabetes (Ebbeson et al., 1999), and the changing dietary patterns among indigenous peoples in Canada and Alaska have already resulted in an increasing prevalence of obesity, diabetes, and cardiovascular diseases (Kuhnlein and Receveur, 1996). A study on cardiovascular risk factors among Kalaallit concluded that an increase in mortality from ischaemic heart disease may be expected in the coming years and that preventive strategies are necessary (Bjerregaard et al., 1997).

The purpose of the dietary survey was to obtain a broad overview of the preferences and the use of traditional and imported foods in the population of Greenland. The questions were restricted to information on preferences and frequency of consumption of a few food items that are believed to be the most important in the habitual diet. The method used gives a relative estimate and not a precise calculation of the consumption of traditional food. Availability and consumption of individual species is highly dependent on the season, and answers given about an average for the last three months will be biased by the respondents' selective memory. Food items that are most common in the diet at the time of interviewing will be overreported, and food items that were eaten the previous month will be underreported.

Part of the regional variation may be due to the fact that the interviews were performed at different seasons in different villages, while in some towns interviewing was spread over a whole year. This particularly affects the distribution of specific food items although the total consumption of traditional food is relatively stable year-round.

In conclusion, this paper describes some sources of variation in the consumption of traditional food among Kalaallit. Consumption of traditional food is related to age, 
TABLE 5. Reasons for not eating traditional food more often given by Inuit in Greenland in 1993-94, including only respondents who did not eat traditional food every day. Comparisons are given for two age groups and town vs. village dwellers. Figures represent the percent of respondents who cited each reason. (They were allowed to state more than one reason.) $\mathrm{N}=$ number of respondents.

\begin{tabular}{|c|c|c|c|c|}
\hline \multirow[b]{2}{*}{ Reason not to eat traditional food more often } & \multicolumn{2}{|c|}{ Age } & \multirow[b]{2}{*}{$\begin{array}{c}\text { Towns } \\
\mathrm{N}=715\end{array}$} & \multirow[b]{2}{*}{$\begin{array}{l}\text { Villages } \\
\mathrm{N}=108\end{array}$} \\
\hline & $\begin{array}{c}18-24 \\
N=157\end{array}$ & $\begin{array}{c}60+ \\
N=60\end{array}$ & & \\
\hline Want variation in the diet & $52.2 *$ & 36.7 & 46.9 & 52.8 \\
\hline Traditional food is difficult to get & 49.0 & 43.3 & $42.8++$ & 59.3 \\
\hline Traditional food is too expensive & $31.8^{*}$ & 48.3 & $41.8++$ & 22.2 \\
\hline Traditional foods for sale are of poor quality & 10.8 & 8.3 & 8.3 & 6.5 \\
\hline Traditional food is difficult to cook & 3.8 & 5.0 & 3.9 & 0.9 \\
\hline Danish food tastes better & 5.1 & 3.3 & 2.8 & 4.6 \\
\hline Dislike traditional foods & 3.2 & 3.3 & 1.8 & 0.9 \\
\hline Traditional food is contaminated & 1.9 & 1.7 & 1.4 & 0.9 \\
\hline Danish food is healthier & 0.6 & 1.7 & 0.6 & 4.6 \\
\hline Traditional food is difficult to chew & 0 & 1.7 & 0.4 & 0 \\
\hline Traditional food lacks vitamins & 0.6 & 0 & 0.1 & 0 \\
\hline Other reasons & 13.4 & 11.7 & 13.3 & 10.2 \\
\hline
\end{tabular}

${ }^{*} p<0.05$, chi-square test for trend for age groups.

${ }^{++} p<0.01$, chi-square test.

gender, and region and is influenced by the current lifestyle, but also by the contact with a traditional lifestyle during childhood. The ongoing urbanization and modernization are shifting the consumption patterns, and trends evident in these data suggest that Kalaallit may consume less and less traditional food if no nutritional interventions are developed. The traditional diet is nutritious and has important benefits for health, but the issue is complicated because contaminants in the traditional diet may pose a threat to health. Future preventive strategies must aim at increasing the consumption of traditional food in certain subgroups of the population, e.g., the young, to maintain a low level of cardiovascular risk factors, but they must also aim at reducing the consumption of the most contaminated species in other population groups.

\section{ACKNOWLEDGEMENTS}

The data collection was funded by Karen Elise Jensen's Foundation. The authors wish to acknowledge the great effort of the interviewers and to thank the participants in the study.

\section{REFERENCES}

AMAP (ARCTIC MONITORING AND ASSESSMENT PROGRAM). 1998. AMAP Assessment Report: Arctic pollution issues. Oslo, Norway: AMAP. 859 p.

BANG, H.O., and DYERBERG, J. 1981. The lipid metabolism in Greenlanders. Meddelelser om Grønland, Man \& Society 2:3-17.

BANG, H.O., DYERBERG, J., and SINCLAIR, H.M. 1980. The composition of the Eskimo food in north western Greenland. The American Journal of Clinical Nutrition 33:2657-2661.

BJERREGAARD, P., and YOUNG, T.K. 1998. The circumpolar Inuit: Health of a population in transition. Copenhagen: Munksgaard. 287 p.
BJERREGAARD, P., CURTIS, T., SENDEROVITZ, F., CHRISTENSEN, U., and PARS, T. 1995. Levevilkår, livsstil og helbred i Grønland. Copenhagen: Danish Institute for Clinical Epidemiology.155 p.

—_. 1999. Helbred, livsstil og levevilkår i Grønland. Den grønlandske sundhedsprofilundersøgelse 1993-94. Ugeskrift for Læger 161(11):1595-1602.

BJERREGAARD, P., MULVAD, G., and PEDERSEN, H.S. 1997. Cardiovascular risk factors in Inuit of Greenland. International Journal of Epidemiology 26(6):1182-1190.

BORRE, K. 1991. Seal blood, Inuit blood, and diet: A biocultural model of physiology and cultural identity. Medical Anthropology Quarterly 5:48-62.

BRENØE, C. 1975. Kostundersøgelse i Grønland 1974. Statens Husholdningsråd. $85 \mathrm{p}$.

DYERBERG, J., BANG, H.O., and HJØRNE, N. 1975. Fatty acid composition of the plasma lipids in Greenland Eskimos. The American Journal of Clinical Nutrition 28:958-966.

EBBESON, S.O., KENNISH, J., EBBESON, L., GO, O., and YEH, J. 1999. Diabetes is related to fatty acid in Eskimos. International Journal of Circumpolar Health 58(2):108-119.

FÜRST, E. 1985. Vår matkultur: Konflikt mellom det tradisjonelle og det moderne. Lysaker: Statens Institutt for Forbruksforskning.

GRØNLANDS STATISTIK. 1995a. Fisker- og fangerfamiliers levevilkår. Nuuk: Grønlands Statistik.

— 1995b. Rapport om levevilkår i bygderne i Grønland. Nuuk: Grønlands Statistik.

- 1996. Rapport om Forbrug i Grønland. Rapport nr. 10 fra unders $\emptyset$ gelsen af befolkningens $\varnothing$ konomiske og materielle levevilkår. Nuuk: Grønlands Statistik.

HEIDE-JØRGENSEN, M.P. 1994. Distribution, exploitation and population status of white whales (Delphinapterus leucas) and narwhals (Monodon monoceros) in West Greenland. Meddelelser om Grønland, Bioscience 39:135-149.

HELMS, P. 1981. Kostundersøgelse i Angmagssalik. Forskning i Grønland/Tusaut 1-2/81. 
. 1985. Kostundersøgelse i Nuuk. Nuuk: Hygiejnisk Institut, Aarhus Universitet. Unpubl. report available from T. Pars, P.O. Box 1626, DK-3900 Nuuk, Greenland.

HELMS, P., and TORELL, K. 1987. Rapport over kostundersøgelse i Thule Jan/Feb, 1987. Nuuk: Hygiejnisk Institut, Aarhus Universitet. Unpubl. report available from T. Pars, P.O. Box 1626, DK-3900 Nuuk, Greenland.

HERTZ, O. 1995. Økologi og levevilkår i Arktis. Uummannamiut. Copenhagen: Christian Ejlers' Forlag og Mellemfolkeligt Samvirke. 215 p.

HOLM, L. 1996. Identity and dietary change. Scandinavian Journal of Nutrition 40:95-98.

HOVELSRUD-BRODA, G.K. 1997. Arctic seal-hunting households and the anti-sealing controversy. Research in Economic Anthropology 18:18-34.

JETTÉ, M., ed. 1995. A health profile of the Inuit: Report of the Santé Québec Health Survey among the Inuit of Nunavik, 1992. Montreal: Ministère de la Santé et des Services sociaux, Gouvernement du Québec.

KROGH, A., and KROGH, M. 1913. A study of the diet and metabolism of Eskimos, undertaken in 1908 in an expedition to Greenland. Meddelelser om Grønland 1913(51):3-51.

KUHNLEIN, H.V., and RECEVEUR, O. 1996. Dietary change and traditional food systems of Indigenous peoples. Annual Review of Nutrition 16:417-442.

MARQUARDT, O., and CAULFIELD, R.A. 1996. Development of West Greenlandic markets for country foods since the 18th century. Arctic 49(2):107-119.

PARS, T. 1992. En kostundersøgelse - foretaget i to nordvestgrønlandske bygder: Saqqaq \& Oqaatsut i 1991. Unpubl. report available from T. Pars, P.O. Box 1626, DK-3900 Nuuk, Greenland.
PETERSEN, R. 1985. The use of certain symbols in connection with Greenlandic identity. In: Brøsted, J., Dahl, J., Gray, A., Gulløv, H.C., Henriksen, G., Jørgensen, J.B., and Kleivan, I., eds. Native power: The quest for autonomy and nationhood of Indigenous peoples. 294-299.

- 1989. Traditional and contemporary distribution channels in subsistence hunting in Greenland. In: Dahl, J., ed. Keynote speeches from the Sixth Inuit Studies Conference, Copenhagen, October 1988. Copenhagen: Institut for Eskimologi, University of Copenhagen. 81-89.

ROEPSTORFF, A. 1997. Den symbolske betydning af kalaalimernit In: Hansen, K.G., ed. Kalaalimernit - Rapport fra seminaret Den sociokulturelle og sundhedsmæssige betydning af kalaalimernit 6. og 7. maj 1997 i Nuuk. INUSSUK- Arktisk forskningsjournal 1: $97-105$.

SEJERSEN, F. 1998. An analysis of hunting and environmental perceptions in Greenland with a special focus on Sisimiut. Copenhagen: Department of Eskimology. University of Copenhagen.

UHL, E., ed. 1955. Nogle undersøgelser af grønlandske levnedsmidler og kostforhold. Beretninger vedrørende Grønland 1955 3(I-II).

WEIN, E.E, FREEMAN, M.M.R., and MAKUS, J.C. 1996. Use of and preference for traditional foods among the Belcher Island Inuit. Arctic 49(3):256-264.

WEIN, E.E., SABRY, J.H., and EVERS, F.T. 1991. Food consumption patterns and use of country foods by Native Canadians near Wood Buffalo National Park, Canada. Arctic 44(3):196-205. 